\title{
Understanding Nigeria Terrorism, its Implications to National Peace, Security, Unity and Sustainable Development: A Discuss
}

\author{
Rawlings Akonbede UDAMA \\ Peace and Conflict Study Program, Institute of African Studies, University of Ibadan, Ibadan
}

\begin{abstract}
Terrorism has been an insidious act common and conducted daily over decades and has been responsible for the physical and or structural violence experienced by many people in Nigeria. Individuals, Groups and even the state carry out acts of terrorism in one way or the other. The preponderance of terrorists' activities in recent times especially those conducted by Niger Delta Militants and now Boko Haram are only in response to acts of terrorism conducted directly or indirectly by the governments and its' functionaries at all levels whose responsibility is to improve and protect the lives and properties of its citizens. The effects of these acts of terrorism are the threats they posed to national security, peace, unity and development of the country. For instance, it has pushed further the polarisation of the fragile political unity and pushed up the existing suspicion and distrust between the 'north and south'. It has also jeopardised the basic human rights and civil liberties of the citizens due to activities of the terrorists and the Joint Security Task Force (JTF) to maintain law and order. Equally, it has threatened the desperate attempt to industrialised, and the existing socio-cultural tranquillity has been hampered. It is recommended that the government should take the business of governance seriously and address issues of injustices, marginalisation, discrimination, and provision of public good such as security and the creation of enabling environment for investments which in turn will increase and improve the livelihoods of the greatest numbers of its citizens.
\end{abstract}

Key words: Terrorism, Insidious, Threat, National Security, and Enabling Environment.

\section{Introduction}

Nigeria is a complex society with about two hundred and fifty distinct ethnic groups, five hundred different languages and a rapid growing population of over 160 million people. Fusing these varied and diverse groups into one unified entity since the amalgamation of 1914 has been a herculean task. The British colonial masters used force to bind the various ethnic nations together. However, after independence in 1960, Nigeria has and continued to experience persistent and intense violence conflicts that has threatened its foundation that culminated into the first civil war fought from 1967-1970. After the civil war, ethnic tensions and civil conflicts has continued and is fast becoming its second nature, culture or the norms of the society. The centripetal forces that have kept the conglomeration called Nigeria together are fast weakening against the centrifugal forces that might lead to its disintegration. The seriousness of the issue could be gleaned from the prediction by United States of America that in 2015 Nigeria might break up.

For most people, the history of Nigeria is that of violent conflicts, chaos, and disorderliness, and retrogression. Some people have become inured to the ugly and obscene pictures of the maimed, charred human bodies, and the wanton destruction of properties as a result of some of the violence reminiscence of the Nigeria civil war. It is possible for anyone to develop amnesia over these horrible violent incidents that have occurred over some decades. And many people cannot live down the orgy of violence resulting to the savage carnage and horror. The overall consequence is that the collective psyche of the people has been affected. Terrorism though not new in Nigeria history, but has become the popular vehicle for instilling fear and conducting violence against the citizens in the country.

In recent times, Nigeria is experiencing a new wave of violence which is terrorism conducted in different forms, means and places. These includes bombing and killing of persons and targeting certain persons and places such the worshiping centres, living homes, commercial buildings, telecommunication masts, government installations and infrastructure, kidnapping as well as depriving people of their legitimate entitlements. These terrorist activities are carried out by non-state actors and do not exclude politicians and government functionaries including security agency that ought to protect lives and properties.

The reason for the ever growing conflict and violence and insecurity is as a result of the dynamics at play between various individuals and groups within. For instance, some individuals or groups seeks to expand their political power based or continue to dominate others without regard to fairness and equity. Again, they are those that seek to occupy or expand land spaces hitherto occupied by others, or seek to be recognised and have fair share by those who feel they own a particular geographical location. Moreover, there is also the highly mobile herdsmen that seek greener pastures of land for their cattle to graze that comes into conflict with farmers 
whose farms are destroyed in the process. Furthermore, they are those who attempt to impose (forcefully) their religious beliefs on others despite the circular nature of the country that permit individual freedom of worship. And finally the government has failed to provide protection of lives and properties to majority of its citizens or create opportunities for employment and self advancement, or bring justice and compensation for those wronged. In all of these as many have resorted to revenge, defending and providing security, and social amenities for themselves hence the government has failed. People that are disenfranchised and lack government support and are unable to embark on self help projects becomes desperation. In their quest for survival they form or join criminal groups as a vehicle to redress or overcome these challenges. When people are driven into a state of helplessness and hopelessness they become desperate. And actions undertaken in desperate situations may lack rationality and due process and is risky and dangerous for the society. The struggle for political power, religious imposition and land disputes and the lack of aid for victims or punishment for troublemakers, corrupt persons, and the mismanagement of the economy have all fuelled tensions in the country. Tom (2012) pointed that in Nigeria, three things are intertwined - religion, politics and ethnicity - and the three are beclouded with corruption, poverty and insecurity.

The recent and incessant terrorist attacks and the precarious state of security especially in the North is as a result of the youth bulges and unemployment. This makes it easy for them to be manipulated by some local people who loath and fear western cultural imperialism. They believe that western education will make their children become spoilt, arrogant and unable to live in rural areas with their parents. And worst they will eventually forget their culture, values and traditions. Already most of them that travelled to cities such as Kano, Lagos, Calabar, Port Harcourt and Abuja finds life in their villages unappealing and unexciting when they visit or return back home. In addition, more than $80 \%$ of the unregulated production and uncared children has led to the pervasive development of over 10 million Almajiris (underage beggars) roaming the streets begging rather than being in school. At the end they surfer economic frustration because they are unable to be gainfully engaged in productive process in the nearest future hence no opportunity of acquiring skills that can guarantee them employments. In a recent assessment by United Nation Children's Fund (UNICEF) statically showed that about 9.5 million children are not in school and about nine million from the north. This is so despite the vast agricultural potentials of the region as varieties of tropical food and cash crops are produced in large quantities. The region also has a lot of mineral deposits which can be mined in commercial quantities (Akevi, 2013). The development untoward social behaviour has been a creation of the leaders in the north which include traditional, religious and political leaders.

The overall consequences are that, since most of them have been negatively employed to wreck havoc against the society, the once bubbling commercial cities, serene and peaceful towns with a perfect blend of modern and traditional exotic cultural heritages have turned into fearful ghost towns. It is almost impossible to assess the painful feelings, quantify the number of invaluable deaths (because some are not recorded) and evaluate the cost of public infrastructure and personal properties destroyed by the terrorists.

Another implication is the introduction of disorderliness, lawlessness and insecurity in the affected areas. Small pockets group of criminals have taken the advantage of the situation to perpetuate other forms of crimes such as armed banditry, kidnapping, assassination and looting of properties.

There have also been cases of human right abuses by the criminals and the security agencies assigned to maintain law and order in the affected areas. These terrorists and the security forces have inflicted irreparable loss on people and their families, coloured the streets with blood, and darkened the clouds with the smoke of uncertainty and now people live in absolute fear.

While majority people see the terrorist as evil persons they do not see themselves as such. They believe that they are legitimate combatants fighting for what they believe in by whatever means possible. They see themselves as freedom fighters and not criminals or rebels as seen by their victims or others. The activities of the terrorists over the past years have posed a serious security and developmental challenges and have threatened the foundation of unity of the country.

\section{Theoretical Perspective}

The various themes on this paper hinges on two theoretical frameworks. The first is public choice theory that explains the issue of public corruption as developed by James Buchannan in association with Gordon Tullock. It is a theory that uses the principle of economics to explain political behaviour decision making. It takes the same principles that economist uses to analyses people's actions in the market place and applies them to people's actions in collective decision making (Shaw, 2012). James Buchannan defines public choice as politics without romance, noting that it is a wishful thinking to presume that participants in the political sphere aspire to promote the common good. Public choice theory like the economics of rational behaviour assumes that people are guided by their own self-interest rather than for the public. Thus, public officials are portrayed as benevolent public servants who act in public interest and carryout the will of the people. In tending to public affairs, voters, politicians and policy makers are supposed somehow to rise above their parochial concern. 
Nonetheless, the behaviours of these people show that they are only motivated by the goal of utility maximization (self-interests). The central theme of this theory is that politicians, bureaucrats and government officials are motivated by personal self choice, rather than to work for the public interest, and putting into practice the policies of government as efficient and effective as possible.

Within the context of Nigeria, government is seen as serving private or special interest group rather than public interests. The politicians and bureaucrats are supposed to be agent of the general public and act in their own interest. However that is not the case. Unless it is in the interest of the agent, they may not act in the interest of the principal. In Nigeria, politic is a game where self-interested businesses, labour unions, and government bureaucrats use the state to enrich themselves at the expense of the public. Government employees will not do their job unless they are paid to specifically to do a task. This is what is called a bribe and is a corrupt tendency.

The second is frustration-aggression hypothesis developed by Dollard in 1939 and Berkowitz's Cognitive Neoassociaition model all illustrate how one may become aggressive through frustration. This theory posited that the occurrence of aggressive behaviour always presupposes the existence of frustration. In another way, frustration is an antecedent to aggression. While Frustration is seen as the blocking of ongoing goal directed behaviour, Baron and Richardson in 1994 opined that Aggression is an action with the intent to harm which can be physical and non-physical (Psychwiki 2010). Frustration here means the thwarting of a goal response, and a goal response, in turn, means the reinforcing final operation in an ongoing behaviour sequence. The existence of Frustration always leads to some forms of Aggression. It also involves the reaction to such blocking. This therefore means that been frustrated includes one's access to reinforcers being thwarted by another party or circumstances and also one's reaction to this thwarting is one of annoyance. Frustration produces a number of different types of response, one of which is instigation to some form of Aggression. Some hostile or aggressive behaviour that occurs is caused by frustration.

Within the context of Nigeria, violent attitudes such as that cause by Boko Haram fundamentalist religious sect in northern Nigeria could be attributed to either the frustration of some political figures that operate behind the scenes to have access to power or due to their inability to introduce Islamic rule in northern Nigeria or even economic deprivations among the youth. Whichever is the reason there have been some form of frustration or the other in achieving their desire goals. The introduction of the two theories is significant because the second compliment the other first. The attitude of some political and economic opportunist has given vent for the terrorism to occur.

\section{Defining Terrorism}

Different definitions have been given by different people, scholars and even organisations based on the way they perceived or experienced terrorism. For instance, the US Department of Defence defined it as the calculated use of unlawful violence or threat of unlawful violence to inculcate fear intended to coerce or to intimidate either citizens, societies, or even the government in the pursuit of goals that are generally political, religious or ideological. The Federal Bureau of Investigation (FBI) defined terrorism as the unlawful use of force and violence against persons or property to intimidate or coerce a government, the civilian population or any segment thereof, in furtherance of political or social objectives. The US Department of State defined it to be a premeditated politically motivated violence perpetrated against non-combatant targets by sub-national groups or clandestine agents usually intended to influence an audience. In 1992, the United Nations defined terrorism as anxiety-inspiring methods of repeated violent action employed by (semi) clandestine individual, group or state actors, for idiosyncratic, criminal, or political reasons, and where-in contrast to assassination where the direct targets of the violence are not the main target. The United Kingdom (UK) in 1974 defined terrorism as the use of violence for political ends and includes any use of violence for the purpose of putting the public, or any section of the public in fear. Adeyemo (2012) opined that the situation can be likened to genocide and defined it as the deliberate and systematic destruction in whole or in part, of an ethnic, racial, religious or national group. Arvind (2009) opined that terrorism may range from socio-economic and political theories based on the personality and environment. It could be motivated from inner drives to revenge or for financial gains. It also could be from fundamentalism to deprivation, political frustration, religious disparities, and resentment against the existing regime, or intervention into personal freedom, oppression, and inequality as well as weak government.

The essential elements of terrorism from the foregoing definitions involves the calculated (intentional) use of unlawful violence to put or produce fear in the public and these acts could be committed by a person, group, and does not exclude the state. It is an adversary acts that influences an audience beyond the immediate victim. The reason and strategy of the terrorists is to draw attention from the populace, organisation and states either local or international. They want to obtain the greatest publicity, and most times choose targets that symbolises what they opposed. 
Sometimes the confusion and difficulties in defining terrorism by some persons is because of the assumption that terrorist activities are conducted only by dissidents, rebels or fanatical groups who are dissatisfied with government policies and programmes and are in contestation with the state for power or to impose their own ideological belief thereby overlooking the fact that the state could equally be involved in terrorist activities against its own citizens either directly or through unpopular policies. Terrorism is a psychological weapon hidden behind an ideological objective either political, economical, or religious demands such as that made by Boko Haram that wants to impose and practice Islamic law in northern Nigeria. It could also be the type conducted by the Movement for the Emancipation of the Niger Delta (MEND) whose activities were aimed at preventing the exploitation and degradation of their land and environment and to have a fair share in the oil revenues. It could also be the (negative) attitudinal conduct carried out by government agents or senior officials to deprive the subordinates of their legitimate rights to gain advantage. Terrorism is by nature political because it involves the acquisition and use of power to advance own interests by forcing others to submit, or agree, to certain demands.

\section{Terrorist Activities in Nigeria}

For keen observers and discerning minds, terrorism is predominant and is not a new trend in Nigeria, and is conducted by those that wield the power either legitimate or illegitimate at one time or the other and in different places. Acts of terrorism are being carried out at homes, in government and private offices, and on the roads either by government officials or private individuals. Many terrorist acts go unnoticed and the victims suffer and endure in silence without the power to react.

The preponderance of terrorists' activities in recent times especially in the northern part of the country does not mean that it is limited to that section of the country alone. Terrorism in Nigeria have come a long way and have been carried out by different individuals, groups, locations and at different times. While some people are the main target of the terrorists, some of the victims are not the main targets but to draw out attention of others. It is the structure and organisation of the Nigeria society that has made terrorist activities to thrive. For instance, a society where the government do not listen or address complaints or the police frustrate citizens with genuine grievances is prone to terrorist acts or violence as people devise means to address their seeming felt problems. The general impression given by the government is that it is only the language of violence that it listens and response to address issues of grievances not matter has serious.

\section{A. State Terrorism}

The State also carries out acts of terrorism against its own citizens. State terrorism is a system of political or economic domination based on the spreading of terror in society. It is characterized by a systematic and massive criminally repressive insidious policy, implemented by the State through its agencies or even direct attack on the citizens to instil fears or inflict pains or death. Most times political actors hide under the umbrella of the state to perpetuate acts of terrorism for their personal gains. For example, Dele Giwa a journalist and Editor-in-Chief of Newswatch magazine was the first to die in Nigeria through a parcelled bomb believed to have been engineered by General Ibrahim Babangida in 1991 when he was military Head of state. However, there has been no official confirmation of his complicity in the death of the journalist. Nevertheless, there have been speculations that Ibrahimm Babangida masterminded the unfortunate incident because the journalist was covering a drug case involving one Gloria Okon that was supposedly death while in detention but was seen offshore of the country. She was believed to be trafficking in drugs on behalf of the ruling class in the country.

In addition, the series of bomb blasts in Lagos state when Brigadier Mohammed Buba Maruwa was the governor in the hay days of the late General Sanni Abacha as Head of State were alleged to be the hand work of the regime. It was speculated that since his (Abacha) regime was illegitimate and lacks the needed popular support, and the protests especially in the western part of the country was as in reaction of the annulment of an election in June 12, 1983 widely believed to be the freest and fairest, the series of bombings were meant to instil fears and divert attention from the popular uprising against the regime. Again, a governor of one of the southeastern states at one time terrorised a Reverend Father when men in his convoy beat the Reverend Father for not leaving the road while he (the governor) drove passed.

Furthermore, the Nigeria security officials have in several occasions been implicated in terrorist activities. For instance, officers in the convoy of a senior Nigeria Naval officer rather protecting, beat and stripped a lady naked in public in Lagos for not given way to his convoy.

Again, besides the fact that the Nigeria police force has been used to protect politicians who steal money from the public till, rather than performing their primary responsibility of protecting lives and properties, have conducted themselves in a manner that needs much to be desired. Though they do not carry bombs and blow up worship places and important installations, but have been a brutal trigger-happy security organ known for their extra judicial killings of citizens. In many instances, they have been involved in terrorising the public through threats and extortions of money from both complainants and suspects alike at their stations and at 
mounted road blocks. Very often, motorists and commercial vehicle drivers easily fall prey to their bullets and die for refusing to give them as low as twenty naira (US\$ 1.6 cents). They torture suspects to death and executing them without trial such as they did to Yusuf Mohammed the leader of the Boko Haram sect who was arrested by the military and handed over to them for further investigation but died in their custody. The bitterness and low perception they have incurred for themselves is as a result of the injustice, unfair and biased investigations they conduct and easily turn the complainant to a criminal. Very many of them reveal back to criminals the identities of patriotic citizens who divulged information about them and in turn the criminals go after them. Some police men have been involved and arrested for armed robbery, kidnapping of persons in the country.

The academic world has not exhibited anything different from the uninformed communities. In schools especially in the tertiary institutions where it is expected that those who impact knowledge at that level should be epitome of discipline, morality, hard work, uprightness of character has shown by far that there is no linkage between intellectualism and morality. Most lecturers who ought to be role models have been involved in terrorising their students into humble submission and to cover up their inadequacy, incompetency or deficiency. For example, they demand gratification and/or to have canal knowledge of the female students in exchange for (pass) marks in class tests or examinations. This is besides the threat of failure for not buying substandard and unapproved text books they authored. Therefore they lacked the discipline of mind required of persons of their station. On the other hand, students who cannot meet up with the demands of academic rigours equally form cults groups which they use as a vehicle to terrorise either the lecturers to award them unmerited marks in conducted tests or examinations and intimidate girls for (forceful) friendships. This is one the reasons that explains the progressive decline in educational standard.

In the political arena, there are instances where prominent politicians are assassinated that are suspected to have been engineered by the states actors. For instance, the late politician Moshod Abiola who claimed to have won the 1983 presidential election was suspected to be murdered by the state while in detention. Others are the late Bola Ige (attorney of law) was killed by people suspected not to be comfortable with his he resignation to return to his party to prepared for the upcoming 2003 elections hence he has served with the ruling People Democratic Party (PDP), while he was a staunch member of the Action Congress. Till date the investigation that led to his death has not seen the light of the day 10 years after his death. Also, there is Funsho Williams, a People Democratic Party (PDP) candidate who was murdered after declaring to contest for the governorship of Lagos. Lagos state is a stronghold of the Action Congress (ACN). Moreover the state has carried out some form of repressive policies that did not only put fears but hardships on the citizens that could be seen as terrorist attacks. For example, the sudden hike in Premium Motor Spirit (PMS) imposed on the citizens during the yuletide celebration in 2011. This single incident sparked-off strikes and series of demonstrations ever witness on Nigeria major roads and streets.

Furthermore, the Chief Executives officers in government ministries, agencies and parastatals carryout act of terrorisms to harass, intimidate, and instil fears in their employees. It is done in the form of unwarranted queries, delays or denying them of their due promotions or premature termination of their appointments. This is especially so when they are perceives as enemies, or based on religious or ethnic sentiments and, to give political advantage to their ethnic lineage. Most often these terrorist acts are done in other to hush or silence the employees while they pillage the organisation with easy. It is this preponderance of terrorist activities that has given the impress that it is the cultural norm of the people to conduct acts of terrorism just in the same way as corruption has.

In Nigeria, most people buy and drive big cars more to impress or oppress others rather than as a means for convenience in movement from one point to the other. Others build many mighty houses not for just the provision of shelter but as a show off how powerful they are economically to intimidate others. It is these reasons that made others to seek desperately either legitimate or illegitimate, morally or immorally to acquire economic power in order to be liberated from intimidation from others or to be able to terrorise others as well, and the circle goes on.

\section{B. Group Terrorists}

There are groups that have carried out terrorist activities against the state for one reason or the other. Some of these terrorists are faceless and their motives are beclouded by uncertainty while some are not and the motives are well known to the generality of people worldwide.

\section{i. The Niger Delta Militant Terrorists Group}

There have been conflicts and tensions between foreign oil companies operating in the Niger Delta region and the indigenous local communities of the Ogonis and Ijaws from the time oil was discovered 1956 and persisted to 1999 when democracy was enthroned. The Niger Delta militants conducted series of terrorist attacks against the government and companies in reaction of the way and manner the multi-national oil companies in 
collaboration of the government conduct their businesses without integrity. These oil explorations caused environmental degradation and pollution of their waters, killing all aquatic animals thereby denying them of the only source of livelihood hence fishing is their preoccupation. The oil spillage also affected their farm lands and cannot produced food. They carried out series of attacks on oil installations, abducting foreign workers (expatriates) which draw attention of the world to their miserable plights. Ogbodo (2010) opined that competition for oil and its wealth and the environmental problem in the region gave rise to agitations, violence and the subsequent extra-judicial killings of Ken Saro-Wiwa and nine others by the Sanni Abacha regime. Since the execution of these prominent people who fight for the liberation of the region by the state and the multi oil companies, the face of the struggle changed and became fiercer. Anton (2011) averred that the Movement for the Emancipation of the Niger-Delta (MEND) a Nigerian rebel group based in the oil-rich Niger Delta gained popularity for their kidnapping of foreign oil workers and bombing of pipelines. Their activities resulted in Nigeria losing out one third of its oil exports. Nwagboso (2012) noted that historically, after the 2007 elections, MEND adopted several approaches to drive out oil corporations and where determined to compel the government to share the oil derived wealth with the Niger Delta region. Onojume (2008) averred that although MEND disclaimed any affiliation with external groups such as Al Qaeda, it clearly engaged in serious acts of violence (terrorism) including sabotage of energy-related infrastructures and kidnapping of foreign oil workers which later became the viable business among the restive youths in the south-eastern geopolitical group in Nigeria.

\section{ii. The Boko Haram Terrorist group}

Boko Haram initially known as Jama'atu Ahlis Sunna Lidda'awati Wal-Jihad is a radical Islamic fundamentalist organisation which is the Nigeria Taliban similar to that of Afghanistan for their ideological stand against anything western and its members follow strict interpretation of the Koran. Onoh (2012) noted that Jama'atu Ahlis Sunna Lidda'awati Wal-Jihad the terrorist group's original by-line in Arabic means 'People committed to the Propagation of the Prophet's Teachings and Jihad'. When translated loosely in Arabic means western education is a sin. This group is fighting for Islamic rule to be imposed in the northern states of Nigeria where Sharia law has already been implemented and they believed that they can achieve their version of Islamic rule by the overthrow of the government. Since then they have been engaged in deadly and well-organised assault in northern Nigeria and attacking Christians and churches mostly.

Since 2001, a new crop of young and daring Muslim faithfuls where most of them are from the semimiddle class and educated have aggressively embraced a stricter version of Islam, rejecting anything Christian and western education and culture, have had undiluted resilience carrying high profile terrorist attacks particularly in the northern states of Borno, Yobe, Bauchi, Gombe, Plateau, Kaduna, as well as the Federal Capital Territory (FCT). They also have freed suspects from prisons, killing high profile politicians, and carried out the first suicide bomb attack in the Abuja police force Headquarters. Professor Martins Crenshaw- a world renowned terrorist expert noted that the activities of Boko Haram signal a fearless come-get-us attitude and some of the bomber as claimed by the Nigeria Vanguard Newspaper are of Somali origin which indicates that they have an active cell in Nigeria. (Anton 2011).

Dele, (20120) opined that the terrorist group operating in Nigeria is a franchise of Al-Qaeda, which has been involved in funding and providing logistics to them. That is why they are so vicious in wreaking havoc in the country with impunity. He also noted that when the Seal an elite branch of the American Marines stormed the residence of the late Al-Qaeda leader Osama Bin Laden in Abotabab, Pakistan last year several documents were retrieved from his residence. Among them were letters between Osama Bin Laden and terrorists groups in Nigeria seeking support. In return, he promised them financial support, training and other assistance. $\mathrm{He}$ particularly linked them with Al-Qaeda cells in North Africa.

Boko Harm's audacity in carrying out terrorist attacks in Nigeria was encouraged by the death of their leader in the same manner the death of the leader of Movement for the Survival of Ogoni People (MOSOP) Ken Sarowiwa did. The group emerged more bitter and aggressive, and daring. The death of their leader Yusuf Muhammad while in police detention in 2009 did not neutralised or dissolves the group but rather rejuvenated them. From time, the police have represented the boots and fist of the government and have been notorious in their injustice, violence and brutality attacks. Little wonder why the police have become one of their main targets as a war of revenge and attrition.

In the light of the sect's ideology or philosophy, not an infinitesimal number of persons from all walks of lives in Nigeria and across the world would not be persuaded that western culture cum education has not produced people of character and competence to move Nigeria from the woods and ensure socio-economic advancement given the high degree of corruption, greed, avarice, covetousness, and injustice carried out by those that have acquired it. However, it is beyond the rationality of most people the linkage between the churches they bomb and western education. Rather than advocating for the return of African traditional religion and practices or at best burn their certificate acquired through western education as some did or refuse to seek 
for jobs with such certificates or/and preventing their people from attending such schools or at worst destroying the schools, they have carried acts that defied the rationality of even an imbecile. Moreover, though the sect did not see anything good in western education, they have not denounce using or deprived themselves from the benefits of the scientific researches and inventions born out of western education such as medicines, automobiles, the assault raffles, communication gadgets, and other information technology equipment which they all use.

It is worrisome that the two religions that often cause conflict in Nigeria all have their roots and foundation from the Middle East. For instance, Islam has its roots in Saudi Arabia and Iraq while Christianity has its roots in Israel and Rome. Most nations from that region that ought to have been an epitome of tranquillity, spirituality, purity and perfection, are embroiled in unending conflicts and perhaps explain the lack of spirituality, morality, modesty, and benevolence among its adherents and the inherent crises in the country, though one is extremely passive and the other violent. These two religions particularly have not led to the production of people with the necessary spirituality and purity of minds devoid of immorality, hypocrisy and wickedness in some persons despite different governments are diverting huge resources to sponsoring pilgrimages to these 'holy' lands. It is my thinking and prayers that once again, the forces of nature should inspire another set of higher human faithfuls to give us a new creed and doctrines to replace the existing 'holy' books which contrast each other and great contradictions even within itselves. For instance it is difficult to understand why at one time God will permit marrying more than one wife and at another, outlawed marrying more than one. This example of the inherent contradictions between the religions is not only causing confusion but debunks the perfection and constancy of Almighty God. This has caused religious apostasy from among informed minds.

\section{The Risk Factors of Terrorism}

There are certain factors that have influenced the birth development, boosted and emboldened terrorists activities in Nigeria. Some will be considered under the following headings.

\section{a) Political Manipulation}

Nigeria practices a presidential democratic system of government which emphases a method where rules and political decisions are reached through majority votes and capitalist economic system that emphasis individual's creativity, hard work and commensurate reward. These systems are not alien to African traditional system except that there practices are not clear cut and strictly distinguished as in the western world. However, most people especially the faithfuls of Islamic religion are opposed to these systems. Radu (2001) noted that democracy is declared un-Islamic by all ideologies of Islamic terrorism, hate capitalism and equally opposed to individualism and believe in a new caliphate that will lead the community of Muslims worldwide into a new world order.

In Nigeria, political contestation has been and is till date to have access to power which guarantee access to resources and revenues and to allocate them to serve self and clannish interest and not for the benefits and development of all concern. This is what has made politics in Nigeria dirty and a deadly affair. The dividends of political victory are usually distributed among a few party loyalist and relations that leaves many people dissatisfied. This system where the winner takes all is a recipe for deadly competition which in turn may results to violence.

Politics has played a substantial role in Nigeria conflicts since it got its independence from the British colonial masters in 1960. Struggle for political power was what led to the Nigeria civil war from 1967 to 1970. Since then, General Yakubu Gowon a military official of the northern extraction that won the war held forth the political power and the reign of governance to 1977 when late Gen. Muritala Mohammed over throw him and became the Head of state and Gen. Olusegun Obasanjo his second in command tool over after he was assassinated by Cornel Damkali Dimka another northern extraction in 1976. An election was conducted under the leadership of Gen. Olusegun Obasanjo and handed over to Alhaji Shehu Shagari in 1979. He was however ousted out in another military coup in 1985 by Gen. Mohamed Buhari again from the northern extraction. His government was short lived as he was over thrown by another military officer Gen. Ibrahim Badamosi Babangida once again from the northern region who ruled for eight years. In less than three months the late General Sanni Abacha who ruled for five years edged out Ernest Shonekon that was brought in to hold forth until election was conducted. The polity became over heated to a breaking point following the annulment of the believed freest and fairest election in June 12, 1993 supposedly won by Moshod Abiola popularly called MKO who died in mysterious circumstances while in detention fighting for his mandate. When gen. Sanni Abacha died in a mysterious circumstances too to perhaps balanced the equation of MKO's death, Gen. Abdulsalami Abubakar took over and conducted in a manipulated election as it was generally believed and the supposed winner the retired General Olusegun Obasanjo was imposed on Nigerians ostensible to compensate the west where Abiola who was denied the opportunity came from. From the foregoing, the exchange of baton remained 
among the military officers from the northern extraction till 1999 when Olushegun obasanjo was sworn in as president.

In 2007, Alhaji Musa YarÁdua was elected as the President while Goodluck Jonathan his vice president however, he died before the end of his first tenor. There was an unnecessary political impasse as a group wanted to ensure that another northerner takes over from where the late President Musa YarÁdua stopped to fulfil the unofficial power-sharing agreement that rotates the presidency every two terms between the north and south by the People's Democratic Party (PDP). The re-election of President Goodluck Jonathan, a southern Christian has in vey great measure engineered social uprising among some northern Muslims especially who feels that another northerner ought to have replaced President Musa Yar'Adua. Alex (2011) observed that Northern grievances were compounded by the re-election in April 2011 of President Goodluck Jonathan, a southern Christian who came to power after the death of northern Muslim President Umaru Yar'Adua. The same northerners continued to argue that Jonathan should have held to an unofficial power-sharing agreement reached in the party.

When President Musa Yar'Adua died in Saudi Arabia it could be recalled that Nigerians were held into ransom by a group that master-minded his corps entering the country through Abuja International Airport at night and was condoned by military personnel and his body sneaked to his home town Katsina state without the knowledge of and involvement of his Vice President Goodluck Jonathan who ordinary would have been in charge. The group was worried about the death of the president and where already apprehensive of the loss of power to Goodluck Jonathan a Christian of the southern extraction. There have been speculations that it is this same group that has transformed into or sponsoring Boko Haran sect to making the country ungovernable.

This same character and attitude of struggling to wield power and dominate others is reflected in ministries and parastatals all over the country. When a certain group of people are at the helm of affairs then all will be well even when they circumvent, manipulate rules and procedures in the conduct of and management of public affairs. They turn these organisations into personal fief and it does not matter if the goals and objectives of establishing them are not met. They dictate recruitments, promotions, and appointments overriding regulations and procedural rules, qualification and experience with impunity to serve selfish, clientele and clannish interests. Some people are discriminated against and are not availed of the opportunities available to others because they do not come from a particular geographical location nor bear certain names, or worship a particular religion, and speak a particular language notwithstanding your qualification and experience. Little wonder why the country has greatly progress retrogressively. Some people or group of people feels that they are born to rule and any time they do not hold the reins of governance, the country should be made ungovernable through violence and disorderliness. They heat up the polity to a breaking point. For them wielding power is the ultimate thing or nothing else should function.

In any case, the political arrangement that has excluded a veritable number of persons from the affairs that concerns them has substantially induced rebellion and encouraged non-state actors using destructive weapons against the government and its people. Those who engaged in violent acts such as kidnapping and arm robbery do so based on the assumption that there is no equality and justice provided by organisations and institutions of the society to encourage people to conscientiously work hard and to earn a decent living.

\section{b) Bad Governance and Corruption}

In Nigeria, government at all levels from the federal, states, and local governments have not fared well in the provision of public goods such as infrastructure, health, education, employment and security despite the enormous oil revenues accruing into their coffers. Many people provide all the services that otherwise would have been provided by the government including security. Monies are allocated to the various tiers of government for the development of their areas but it is diverted by those in position of authority into private pockets. Gwom (2011) opined that kidnapping and terrorism are signs and consequences that formal authority is ineffectual and checks and balances in governance are not working. Despite stupendous wealth in the country, majority of the youth lack or have low or access to (quality) education and employment. This is made worst by the inexplicable wealth displayed by those whose rise to fame could only be traceable to few moments of lawlessness or defiance of order rather than to hard work. Most of the youth learn from those they see as models even if they are not doing the right thing. Some of the super rich were former coup plotters turned Head of States and their retinue of appointees. In addition, they are those who looted the ministries and parastatals dry by taking advantage of the loose judicial and weak enforcement arms of government. The collective wealth of the people has been appropriated by a few opportunists. At one time, a certain governor of one of the states that Boko Haram took its roots boosted to the press that he having seventy eight brand new four runner jeeps packed in his residence in the face of wallowing poverty that has engulfed the entire state.

Every month and occasionally, the north is allocated huge amount of money in hundreds of billions of naira from oil revenue and taxes from commodities they (Muslims) prohibit, however, there is nothing to show for these huge revenues that have accrued into their states coffers. The northern elite's corrupt attitudes towards 
the masses have been incredible. These monies only ended up in the pockets of the few that has produced and nurtured the Islamic sects they will want to abandon after training and using them. Of course the skills they have acquired will have to be used to survive even if those that trained them no longer need their services. It has been the vehicle used to express their anger on the ordinary Nigerians. Boko Haram insurgency is thriving in the northern parts of Nigeria because their governments are greedy and corrupt, injustice and marginalisation is prevalent and unemployment is rift. As long as these issues are allowed to continue to run, people will continue to agitate for their rights in whatever means. The Nigerian elites are known worldwide for their heartless greed and theft of public funds, avarice and disdain for the common man. This grand larceny is common to all tiers of government in Nigeria. They are the foremost terrorist group because their acts have caused avoidable maimed and deaths either by roads or airplane mishaps that are frequent. There is the poor health care system that is responsible for the fear, bereavement, emotional torture and psychological pains experienced by many resulting from deaths of their love ones. All these are the consequences of the shameless looting of public funds which is worst than that caused by Boko Haram's activities.

Furthermore, the leaders mindlessly marginalisation and sidelining of a substantial number of people from the mainstream of activities even those where the natural resources and revenue is drawn from by using instrument of force and intimidation is capable of inducing violence. This prolonged marginalisation and deprivations in the face of plenty has led people to become desperate and willing to die rather than endure the dehumanising conditions they find themselves. Terrorism will continue to prosper due to wide spread injustice, oppression, marginalisation and extreme poverty among the people.

\section{c). Youth Bulges and Unemployment}

Over the years, there have been growing numbers of, and development of feral children produced across the country without the corresponding care and upbringing. Consequently, these children who soon grow into adults lacked the needed qualifications and skills for meaningful and gainful engagements for survival. Because of this they idle away which make them pruned to rebellious tendencies. It is this condition that has enabled the mischief makers to use them for evil activities. This is in line with the assertions of Murphy (2001), and Kristof (2002) who pointed that when a group is absolutely or relatively deprived of the necessities of life they rebel. Unemployment and zero opportunities for advancement have resulted in the Boko Haram to easily obtain a substantial and growing support base. Economic inequality leads to political conflicts (Anton 2011). After the northern governors meeting, the chairman of the forum Dr. Babangida Aliyu of Niger State attributed the country`s present challenges such as poverty, unemployment, youth restiveness and violence are manifestation of rejection of core values such as honesty, fairness and justice in their communities, societies and indeed the nation. And that they have allowed greed, corruption and incompetence to overwhelm them overtime (Nigeria Tribune, 2012). Similarly, the sultan of Sokoto Alhaji Muhammed Sa'ad Abubakar III, stated that insecurity and other associated challenges bedevilling the Northern region were self-inflicted by northerners. He said whatever that is happening in the North is our own doing, because we did not do what we are supposed to do (Akhaine, Taiwo, and Akinola 2013). People without meaningful source of livelihood usually lack dignity, confidence and self esteem, and after a long time may be prone to aggressive behaviour and violent acts due to frustration. The government is out of touch with the plight of its citizens. A combination of factors such as untrained youth bulges, corruption and minuscule tax base has deprived the people of the necessary funds for the establishment of industries and other developmental projects.

It sounds odd and strange that some people continued to blame and attribute terrorist activities, and why some volunteered to carryout suicide bombing against innocent citizens and destroying properties that caused high degree of mayhem on unemployment. The agricultural sector was the mainstay of Nigeria economy that could accommodate both skilled and unskilled persons such as that which produced the groundnut pyramids in the north, cotton, palm oil and cocoa in the south, west and east that were exported in 1950s, 60s and 70s is still there and will do the same if given attention. However the employment recognised today is politics. People contest and struggle for political offices to enjoy free money while others suffer environmental degradation resulting from oil exploration. People rather than developing their human capital base instead develop networks (powerful connections) that can create non existing jobs and offices without regards to self worth and skills that can lead to productivity.

It is difficult to rationalise that economic deprivations and grievances can propel any person or group to carry out extreme acts of violence against people they have lived together for so long. Dele (2012) noted that people have made allusions to all kinds of problems that seem to suggest that the north has suffered more economic disadvantages than other regions in Nigeria. He pointed further that if the north suffers from massive unemployment and lack of opportunities in the north the problem is even more amplified in the south or other parts of the country. So it is far from the truth. In the north, south, east and west, there has been a significant growth over the years in the population of the underprivileged and have suffered from inequalities and lack of access to basic needs. However, they have been silence by oppression and have not attempted to carryout 
bombings to drive home their plight. The issue of unemployment is a global phenomenon in recent times though it varies in degree from nations to nations and state to states. Nowhere in the world has this problem prompted the affected segment of the society to carry out such magnitude of violence and killing the innocent citizens. The Taliban in Afghanistan and the Al-Shabba in Somali has not claimed so. So the case of Nigeria should not be an exception.

There is unemployment problem in other political zones if not more. There is multitude of youth in the west, east and south that are not employed but have not resulted to suicide bombings and killing the innocent to attract attention or to address the problem. However, most of these unemployed youth have indulged in other forms of crimes such as arm robbery and kidnapping which in their own thinking can redistribute wealth into their hands and not killing innocent citizens. Moreover, even if unemployment is particular acute in the north, they have not ask the reason for this development. They are not unaware of the youth bulges in the region resulting from mass birth without corresponding care, training and human capital development. A situation where some men will have over seventy children does not augur well for the region or country. This has given rising to the Al-magiri syndrome. This practice is not exclusive to northerners alone except that the degree differs. In the southwest men have multiple and maintain concurrent affairs with women and get them pregnant then abandon them which have resulted to the 'area boys' syndrome. When children are produced without care and training, and left to fend for themselves through scavenging and collecting food from the dust bin, they are naturally bound not to realise the value, sanctity and dignity of human life. Again, when children are pumped with goat food or allowed to feed like goats, they certainly will behave like goats and be a threat to others. It is this reason that Governor Raji Fasola of Lagos state signed a law against parents that abandon any child recently.

\section{d). Religious Manipulations}

Religion plays a great role in the lives of its adherents all over the world. Religious ideological indoctrination and its manipulation have played immense role in conflicts or civil unrest in Nigeria. Most conflicts in Nigeria have been given religious colouration where heinous crimes such as maiming and brutal murder of fellow citizens and wanton destruction of properties and homes have been carried out. Though, some people believe that the religious aspect of violence in Nigeria exploits the secular issues such as poverty, inequality and injustice to revenge killings of Christian and Muslims. For instance, a report by a joint high level Christian-Muslim taskforce comprising the World Council of Churches (WCC) and the Royal Jordanian Aal Al Bayt Institute (RABIIT) delegation believes that the primary causes of the current tension and conflict in Nigeria are not inherently based in religion but rather rooted in a complex matrix of political, social, ethnic, economic, and legal problems among which the issue of justice or the lack of it looms large as a common factor (Anglican Communion, 2012). The Sultan of Sokoto who is the President General of the Nigeria Supreme Council for Islamic Affairs (NSCIA), Alhaji Muhammed Sa'ad Abubakar III, said emphatically that nobody can Islamise Nigeria and condemned the activities of Boko Haram in some parts of the North. He noted that no good Muslim or Christian will be part of the insurgency meant to disintegrate the country, and that none equally can impose his religion on the country (Akhaine, Taiwo, and Akinola 2013).

Since 1999, some states in the north have introduced and implemented Sharia law which is hoped to translate to a prosperous and peaceful life. However, it has failed to usher in the necessary development and the Eldorado hoped for among its adherents in the region. This is so despite the fact that leaders who are believers of Islamic faith have continued to involve in massive corruption, marginalisation, discrimination, and deprivation that has kept the region backward. Given this scenario, It is hardly possible to rationalise why a certain group of people would want to make the world believe that the absent of Islamic rule is responsible for the woes experienced in the region when it is already in practice. This goes to show that it is not the system of government adapted and adopted that can lead to the achievement of societal goals and better life but the people who are in control of the system that can to lead to the attainment of the desire goals. So no matter how heavenly or angelic a system is, if the actors or operators of the system are not righteous the system will fail to give the desired results. Lack of effective and selfless leadership has been the cross and the unfortunate majority of Nigerians.

Those who hide under the name of religion and indulge in violent acts are exhibiting high degree of ignorance and lack of the knowledge and understanding of the Greatness of Almighty God. God that creates the heaven and earth cannot suddenly become ineffective and unreasonable to inspire an ordinary mortal to force and intimidate others worship Him or maim and kill another human being they cannot create. There is the need to be wary about the activities of some persons so that someday it will not behove on a group of persons to claim that they have a mandate or inspiration from an unknown god to force people to speak a particular language or have our lives terminated.

It is worrisome that State Governors and Heads of ministries, agencies and parastatals divert monies appropriated for developmental programmes in their states and running of public offices to sponsor certain 
classes of persons for pilgrimages. Any yet most of them do not see anything wrong in their covetous attitudes, discrimination and marginalisation, stealing of public funds and other corrupt practices in offices they hold in their daily lives. Some equally use voodoo practices, and sacrificing human beings in order to retain positions they occupy in their offices despite the religiosity they professed.

We have not pondered why the most popular religions came from the same source - Middle East with unending conflicts. And that as worshippers of either of these faiths they must embark on pilgrimage there to obtain salvation, and what God will do or happen to people that worship other religions or those that do not know either Christianity or Islam today. Again, it is difficult to imagine how many of them will have made it without the invention of airplanes courtesy of western education they presumed to hate. Moreover, they do not see anything wrong in diverting money meant for the development of their areas for the benefit of all concern to sponsoring a few persons to embark on pilgrimage trips which has continued to attract foreign exchange to these countries from fares charges (most airlines are owned by the host countries), hotel accommodation, feeding and other sundry expenses.

The worst is that back home, companies that would have provided employment opportunities are abandoned and have become moribund or in comatose while some have totally collapsed. Besides, there is no accessible and affordable health care system, no portable drinking water, electricity and other infrastructure to improve the lives and living standard of their citizens. It is this situation that Alex (2011) observed and noted that the government of the northern states have failed to eliminate corruption, revitalize the northern economy, and address the north's feelings of political marginalization despite the implementation of Sharia in northern states from 1999 to 2001. It is one of the reasons why the Islamic sect movement have been able to draws substantial recruits by capitalizing on the disappointment many northerners felt about their governments.

Nevertheless, though Boko Haram wants ordinary Nigerians to believe that to impose the purest religious principles and practices is their main aim and objectives, but what they really want is political power. They are indirectly making a demand for political power and control of the north and perhaps Nigeria at large. However, they are equally aware that this kind of demand is impossible to achieve through dialogue and diplomacy hence they have resorted to suicide bombings and killing innocent defenceless citizens, destroying properties which is similar to groups such as Al-Shaba in Somali and the Taliban in Afghanistan. They have resulted to using instrument of fear such as threats and deaths to frighten and turn the people against the government.

Attempt at bring to an end the activities of Boko Haram by calling them for negotiation has proved abortive and they have largely remained faceless which has given the impression that they lack genuine complaint. Onoh (2012) averred that the true motive of Boko Haram either it is a religious objective, or simply criminal gangs with an indefinite ideological mindset continue to shift from one statement and demand to another at any given chance. Given their successive mixed messages and conflicting demand shows that they are a group of people who ultimately engaged in a struggle for the control of political power or absolute power in Nigeria. So, this act of terrorism in the name of Islam is a concealed attempt to achieve a political gain. And that it is even true when an informed source noted that the Muslim terrorists are drug dealers and addicts, rapists and adulterers.

Moreover, there is little wonder and curiosity why the leaders and sponsors of this magnitude of violence do not directly volunteered themselves or their children to strap bombs on their waist and carryout the bombings if their acts are selfless and of noble ones and truly believe in the benefits of heavenly bliss as they persuade their uninformed foot soldiers. This is because they want to stay alive and rule and enjoy the lives they sacrificed which do not mean anything to them. So it is a political motive. In addition, there is no guarantee that when Islamic rule is established in northern Nigeria there would not be polarisation within the Islamic faith as in the case of the Shitts and the Sunnis in Iraq, Pakistan etc that engaged in reprisal killings daily.

\section{e). Internal Conspiracy and Collaborators within Government Cycle}

Some groups of terrorists have continued to carry out their activities because they enjoy enormous support from a great number of people within the country and even from the ruling class. Sometimes President Goodluck Jonathan acknowledged that a good number of terrorists are in his government. This explains why some of the suspected terrorists arrested could easily escape from maximum detention centres and release their members without qualms. However, it is difficult to understand why the president has not been able to fish them out to face the laws of the land.

Furthermore, the public have not help matters because most of them are either in support of the terrorists or for fear of being attacked. This is particular so because they have not been able to give intelligent information to the hiding places and activities of the terrorists. Intelligent reports alleged that some communities were shielding members of these terrorists groups from security operatives. Dele (2012) pointed that the conspiracy of silence over the activities of these terrorist in the north is a source of worry even when their activities have turned the entire area into a pariah zone. No prominent figure from the north has come out openly 
to condemn these terrorists. He further pointed that there are moles in the security apparatuses of the nation that support these sects and some unscrupulous Nigerians are recruiting and giving tacit support to these terrorists. Otherwise, it is difficult to explain how large contingents of foreigners entered the country by road and drove all the way into Abuja the centre of the nation with no defined mission or even proper destination without being noticed or accosted on their way by the security agents. Such people are brought into the country, indoctrinated by the terrorists and used as foot soldiers by unpatriotic Nigerians for dastard activities. Sometimes when these unwanted migrants without definite purpose are prevented from entering the country by the Nigeria Immigration Services by deportation those who bring them devise other ingenious means and returned them back into the country. Sometimes the terrorist group overwhelmed or threaten the security agents at the border post when they are confronted. In addition, it is also quite possible that the expertise in bomb making and well coordinated and orchestrated attacks could come from within the security forces or former soldiers such as Mohammed Yusuf.

\section{f). Globalisation and Poor Security Networks}

In many instances, the world has opened up and societies have become closely-knitted together. There have been free movement of people and goods due to trade liberalisation. And with the development of modern infrastructure and new technologies in communications, e-banking and payment system things are done with relative ease. For instance, banks have provided easy access to international payments system and funding which has been exploited by terrorists to sustain their activities. Dele (2012) pointed that more than 200 suspected terrorists from Niger republic had entered the country through the porous borders and were intercepted and arrested by military undercover agents in long vehicles conveying them to Abuja at night. When they were asked about their mission and destination they could not offer any explanation. They did not even know where they were going to or what their mission was. He equally noted that the tactical sophistication with which Boko Haram has been carrying out their attacks shows a link with al Qaeda in the Islamic Maghreb (AQIM) terrorist groups. Boko Haram's used of large bombs is an indication that it is receiving training from AQIM, as well as encouragement to attack more ambitious national and international targets just as the double car bombings of the U.N. office in Algeria in December 2007.

The activities of terrorists cannot be attributed to any single factor or one variable cannot explain adequately the reason for their violent activities in Nigeria. Ailemen, (2011) and Ikuomola (2011) noted that in late September 2011, a committee set up and chaired by Ambassador Usman Gaji Galtimari outlined the key causes of the unrest, and blamed the federal government for the continued threat to national security by the Islamic sect. For instance, the existence of private militants that were established and funded and use by the politicians and individuals and were later dumped after they have received training in the used of arms; the existence of Almagiris that could be used as cannon-fodders to ignite and sustain the crises; there is the influx of illegal alien such as a sect leader Abubakar Kilikam resulting from fenceless porous and unmanned borders and also include those manned by government officials; the government has also failed to bring justice and bring relief for the victims of the crises, reported that high level of poverty and illiteracy existing in the North-East zone; massive unemployment of youths both skilled and unskilled and weak governance that failed to deliver services in the wake of huge resources accruing to states and local governments areas. It also include the provocative inciting preaching by some religious leaders were all responsible for the upsurge in violent activities in the north.

\section{The Danger Ahead}

The continued terrorists activities is a dangerous trend that posed as a serious threat to the security, peace and unity of this country. Already the reprisal attacks by the northern Christians are making the already volatile area to be more risky.

The Niger Delta has warned that the north should be careful with the terrorist activities carried out by some of their people because they do not have the monopoly of violence. They attributed the upsurge in terrorist activities to the fact that a southern minority Christian is the president. And that such large scale violence did not happened when those from the north held forth the reins of government for over three decades. They warned that that if it continues and anything should happened to their kins man they will retaliate and ensure that this country breakup. The activities of the Niger Delta militants is not unknown to many especially when they held the country to ransom by bombing oil pipelines and installations and Nigeria was losing huge revenue besides human casualties.

Recently in Enugu after an emergency meeting that was held where over thirty different Igbo youth movements attended threatened to commence reprisal attacks on all northerners in the southeast if the federal government failed to checkmate the increasing spate of bombings of churches in the North that affects most of their relations that worship there. There is no denying the fact that if this threat is carried out the entire nation would be caught up by violence. Groups and communities will set up against each other and the effects will be enormous. All ready the reprisal attacks from the northern Christians youth is making the bad situation worst. 


\section{Effects of Terrorism}

Political, religious or ethnic-based instability within a country has the potential to imperil peace, unity, economic and social development in Nigeria. Though the terrorist groups are mostly based in the north fighting for an unidentified cause at present, its potentials to disrupt the entire country are high. For instance, the activities of terrorist have paralysed almost all sections of the country. It had breached peace, threatened the unity and impeded economic progress and development of Nigeria.

\section{A. Social Effect}

Terrorism has had a negative impact on the people regardless of status and the society at large. It has disrupted and offset the normal social life and a good number of innocent lives have been lost. Terrorists' activities have dislocated people from their usual bases to different unintended locations. The mass movement of people creates refugee problems with substantial costs to the individual, host communities and the government.

In addition, these episodes of violence has hit strongly against and disorganised the socio-cultural tranquillity, the fragile religious tolerance among the people and polluted the serene and spiritual based of the environment. The human costs in terms of lives and properties can hardly be valued and quantified since the upsurge of the violence began.

\section{B. Political Effect}

Since the rise of Boko Haram, the Islamic sect in spreading terror in the last three years, spreading clouds of fear across the country, and especially in many parts of the north where law and order has collapsed. Different murderous gangs roam the nooks and crannies of the cities, streets and villages day and night exploding bombs, shooting and killing innocent people. They set homes and business premises on fire, destroying places of worship, and attacking security agents and institutions. The process has promoted anarchy by causing confusion and widespread panic among people in Nigeria.

The civil rights of individuals and even their more basic civil liberties as guaranteed by the Constitution has been jeopardised. While the Islamic sects unleash terror on the people, the activities of the security agents have become deplorable as well hence the abuses of people's liberty have become the order of the day. They have deployed an unconventional and extra-judicial method of shoot at sight which is usually adopted by the government to tackle widespread public disturbances and terrible crimes. The security agents stop people at will, restrict people's movement by the day and especially at night and kill anyone at the least suspicion.

The sects' activities have spread fear across the length and breadth of not only northern Nigeria but the entire country especially among the political elites. Given the ethnic sensitivity of the country, it has pushed further its political polarisation and raised the existing suspicion and distrust especially between the north and south.

\section{Economic Effect}

Extreme violence repels rather than attracts business investors as in the case of the activities of Boko Haram. When human, material and financial resources are channelled into the advancement of sectarian ideology, economic development is retarded. The violence afflicted in northern Nigeria has affected business and economic activities have slowed down.

Moreover, the movement of people to these zones that would have buster economic activities have been stalled. Terrorism has already worsened the development space of the region as it has scared foreign and local investors alike and limited the earnings from tourism. Jos the capital of Plateau State that was once the pearl of tourism and a dream home for most people across Nigeria has become a shadow of itself. There is no doubt that wars, terrorism had led to political instability which in turn have a significant negative effect on the economies in which they take place. Terror attacks are known to cause decrease in aggregate private investments.

The orchestrated attacks on vital government installations, infrastructure and investments have sent northern Nigeria to the brink of development. One of the most obvious effects is the distress it has caused to local businesses and the people who reside in that part of the country. The violence has caused the destruction of lives and property in the north thereby paralysing economic activities in the region in spite of its natural endowment in agricultural productivity.

It has succeeded in creating fear and terror that has hunted everybody and the productivity of people has been stalled. Most economic activities have come to a halt due to uncertainty in the country. It has paralysed economic activities especially in the northern parts of the country were these incidents are prevalent, thereby worsening the already bad situation. It also has disrupted economic activities because people fear to go to the markets to transact business because they do not know where the next attempt will be. The northern part of the 
country that used to be a major food supply to the entire country has been fled by people living in the region. This has had adverse effect on food supply and prices as well. Northern Nigeria that is trying desperately to industrialised but with a dangerous group such as Boko Haram, investors either foreign or local cannot invest in an unstable environment.

\section{Recommendations}

The security of people's lives and property is absolutely necessary for social peace, political unity, and economic development and prosperity on a large scale. Assessing from the operational position of Boko Haram it is impossible to avail themselves for negotiation for various reasons. The objective of the sect is not only absolutely unrealistic and unpopular even within members of their religious faith, but unattainable. Accepting to negotiate will reveal their true identity which they dread. This is besides the social stigmatisation, and hate that will come from the public. There is also the fear of vengeance being visited on them by the relatives of those they have caused so much misery or prosecution by the government. In the light of the forgoing, the following suggests are put forward as a way out of the problem.

\section{A. Campaigns for Right Religious Indoctrination and Positive Values}

Religious beliefs plays significant role in Nigeria social unrest in no small measures. Since wars starts in the mind, it is necessary that a well orchestrated against hate and violence campaign should be carried out in order to change the mindset of various groups of terrorists.

It is vital that the clerics of the various religions should teach and continue to preach the right doctrines and good morals to their adherents. True patriots should continue to pray that God should someday in not too far future reveal Himself or inspires yet new faithfuls to give humanity new creed and doctrines that will guarantee peace and harmonious living. While God tarries, there is the need for a revision of the 'holy' books because of their seeming irrelevance in today's realistic world. For example, it is said in one of the 'holy' books that whatever that is banded on earth it will be accepted in heaven. So, when a group of persons decided to rape and/or kill an innocent person, it would be accepted in heaven. This is one example out of the thousands doctrines in some of these 'holy' books. If there was the need to have the New Testament bible, it has become absolute necessary and urgent to have a brand new or revise of the entire 'holy; books. The revision can do well to begin with the symbols or emblems that serve as identity of some religions because of their fearful nature they inspired even at a glance. They do not signify peace inherently.

\section{B. Improve Governance}

It is high time the various levels of government should take governance as a serious business especially in the area of security and provision of public goods such as improved infrastructure and the creation of the enabling environment need for investment that would in turn creation opportunities for employments. The government should address the myriad of problems such as poverty, corruption, unemployment, drug trafficking and abuse etc which are the likely precursors to violent reaction and the consequence insecurity.

\section{Addressing Youth Bulges and Unemployment}

There is no gainsaying the fact there is the up surge of the population of the young ones who are unemployable for lack of required skills and that all tiers of government cannot absorb the current unemployed population into its work force. It is simply not possible especially when agriculture has been relegated to the background because it is seen as dirty, hard and does not yield quick and enormous return as compared to politics in Nigeria. It has become imperative for the government to enforce the national policy on population. The current policy four children per couples should be backed up with parent irresponsibility act where punishment is imposed on any erring couples, or person(s) who produce and abandoned any child. When this is done, it will go a long way to stemming the number of children produced by couples.

\section{Review the Existing Land Laws}

In Nigeria, the traditional land tenure system prevents commercial system of agriculture because land is shared to the members of the family especially after the death of the father. This fragment ownership of once whole land prevents people from holding large parcels of land to invest in agriculture. If there people can design a system for cooperative land holding so that it will be enough for meaningful farming and commission paid, it will be better. Or the government can acquire land and due compensation paid and make it available for big time farmers it will improve agricultural productivity.

Again, laws that inhibit the exploration of mineral deposits by individual states except by the federal government should be reviewed. The existing land laws give room for illegal exploration of mineral deposits by a few persons without consequences. If this is done, it will enable the states to invest which will create job 
opportunities. This would keep some people busy rather staying idle and be willing tools in the hands of mischief makers.

\section{E. National Dialogue}

There should be a national dialogue involving all ethnic groups that will determined how this country should be governed given its multi-multi ethnic diversity in terms of culture, religion and traditions. It will encourage all Nigerians to re-new their commitments to brotherly love, tolerance, forbearance, moderation, goodwill and mutual understanding. But the fear of some groups opting for total resource control has been the stumbling block for this initiative that would have serve as panacea for peace in Nigeria. But the truth is that in one way or other, the issue of true federalism will be address and solved but the prayer is that it should not be through violence or civil war.

\section{F. Improve National Security}

Since it is obvious that terrorist groups would not negotiate for fear of being identified, how it will difficult for them to stop their activities even when subdued by the government. They will continue with their activities even if it means doing so sporadically to massage their pride and ego. In this case, it behoves on the government to improve the security networks by improving the capacities of its security agencies. This means that the government will have to invest heavily in counter terrorism by training of its security personnel and educating the public on matters of security. Manpower development and capacity training is imperative, personnel motivation through assurance policy is necessary, and should engineer a synergy between security agencies which will culminate in intelligence sharing. This should be accompanied with the introduction of electronic gadgets such as metal detectors, security walk-through troughs, CCTV cameras, convex mirrors, and atom detectors.

Furthermore, Core intelligence agencies such as State Security Services (SSS), the National Intelligence Agency (NIA), Directorate of Military Intelligence (DMI) and Defence Intelligence Agency (DIA) should be encouraged to work together for success. Those at the border control points such as the customs should tighten the noose on the importation of illegal proliferation of Small Arms and Light Weapons (SALWs), explosives and other offensive weapon. Similarly, the Nigeria Immigration Services (NIS) should mount a formidable campaign against the influx of illegal immigrants and effectively monitor the international borders. First the government must build border fences around its boundary and take it seriously on any assault on officers by any individual or group(s).

\section{G. Collaborating with Others}

Terrorism is a phenomenon which must be condemned, resisted, fought and eliminated at all levelslocal, regional, states, and national. Conditions necessary for wiping out terrorism must be cultivated and strengthened at all levels. There is the need to form and collaboration bilaterally or multilaterally with the neighbouring states to fight terrorism. Terrorist acts confronted by a state cannot be eliminated by the affected States alone. This is because of the international linkage of the terrorist groups. It is, therefore, clear that all the nations must form a common front to fight terrorism. Institutions such as Economic Commission of West African states (ECOWAS) and African Union (AU) should do more than rhetoric. They should walk the talk.

\section{H. Addressing Injustices}

Violence is as a reaction to individual or groups acts of despair and of a people that sees no future because it is vastly ignored or frustrated by government unfair practices. There is the urgent need to identified and justly resolve the political, economic and social grievances nursed by the aggrieved. Most of these deeply felt grievances are legitimate which resulted from manipulations of rules and processes to favour certain persons. There is also the widening income differentials of employees of same horizontal levels in same organisations or different organisations, and the wide economic gulf between the rich and the poor. Moreover the bad leadership which reflects in poor governance, economic mismanagement, rampant corruption, and painful economic reforms all constitute significant part of the sources of deprivation resulting to misery and despair that needs to be addressed. These varieties of factors have alienated a veritable numbers of persons or groups and have made the resort to violence inevitable.

\section{Conclusion}

Terrorists' activities are second nature to Nigeria. It is carried out by individuals, groups in both private and public places and offices including the government you least expect. It is government terrorism that has given birth to other forms of terrorism conducted by individuals and groups. The increased terrorist violence caused by Boko Haram in recent times is enormous and is a great challenge to security, peace, unity and development of the country. 
Besides terrorism instilling constant fears, and destruction of lives and properties, it has threatened the fragile foundation of Nigeria's unity and development. To address this issue, as it is said charity begins at home, or remove the log in your own eyes before removing that of the other, the government must first end its own aspects of terrorism before it could have the courage to address that conducted by non-state actors such as Boko Haram.

Boko Haram terrorist sect cannot submit itself for negotiation or dialogue but if they do the better. So far, the security agencies (State Security Services and Army especially) are doing well. However, the government must intensify efforts to confront the sect by devising means and strategies to clamp down on them. Empowering and improving the security apparatuses and acquiring security enhancing gadgets and tracking devices will be a good starting point.

\section{References}

[1]. Akevi, J., January 15, (20130. Northern Governors and Street Begging. The Nation Akhaine, S., Taiwo, I., and Akinola , T., January 15, (2013). North to blame for own woes, says Sultan. Nigeria Guardian

[2]. Aliyu, B., (2012). Northern governors blame challenges on values' rejection. Nigeria Tribune 22/08/12

[3]. Anglican Communion News Service, (2012). Sectarian violence in Nigeria is beyond religious tensions. Retrieved From http://www.aglicancommunion.org/acns/news.cfm/2012/8/1/ACNS5163

[4]. Anton M.P., (2011). Suicide terrorism in Nigeria: a look at the Boko Haram. Retrieved from: http://www.consultancyafrica.com.index.php? On October 22, 2012

[5]. Anton, M. P., (2011). Suicide Terrorism In Nigeria: A Look At The Book Haram. Retrieved from: http://www.consultancyafrica.com/index.php? on July17, 2011

[6]. Arvind, S., (2009). Impact of Terrorism on Social, Economic and Legal Structure of the Countries Obstacle to Global

[7]. ALEX, T., (2011). Nigeria's Terrorism Problem: Why the suicide bombing of the U.N. compound in Abuja isn't just a lone incident -and why it could spark an ugly religious war in Africa's most populous country.

[8]. Crenshaw, M., (1981). The causes of terrorism. Comparative politics, 13(4):379-399.

[9]. Dele, A., (2012). Fighting Terrorism in Nigeria. The Nation. On 01/08/2012

[10]. Gwom, S.,( 2011). Source: War Against Terror in Plateau State: History of Kidnapping and Terrorism in Nigeria. Retrieved from: http://www.causes.com/cause/559771-war-against-terror-in-plateau-state, on December 25, 2012.

[11]. Ifeayi, L., (2011). The Impact of Terrorism in Nigeria: In view of the recent Attacks by Boko Haram. Retrieve from: http://www.blogger.com/ on July 17, 2011

[12]. Ikuomola V., September 27, (2011). Committee knocks security agencies for rivalry. The Nation.

[13]. Kristof, N., (2002). What Does and Doesn't Fuel Terrorism. Global Policy Forum - 9/11, 8-5-2002.

[14]. Martha, C., (2007). Terrorism in Context. The Pennsylvania State University press. http://www.psupress.org.

[15]. Murphy, J., (2001). 'End Terrorism List Archive: Focusing on Shadow Theory/Causes of Terrorism'. Global Learning Group, Education Development Center Inc, 10-9-2001.

[16]. Nwagboso C. I., (2012). Security Challenges and Economy of the Nigerian State (2007 - 2011). American International Journal of Contemporary Research Vol. 2 No. 6; June 2012

[17]. Ogbodo, S. M. (2010). Environmental issues and Nigeria's Niger- Delta crisis: Implication for sustainable development and global peace" OIDA International Journal of Sustainable, 12 (2), 125-173.

[18]. Onoh, A. J., (2012). Political Terrorism in Nigeria: Boko Haram - the People and the Government. Retrieved From: http:/www.ngex.com/news/public/article.php?

[19]. Onoyume, J., September 22, (2008). JTF Accuses MEND of Plot to use Hostages as Shield. Vanguard Newspaper.

[20]. Psychwiki,(2010). Frustration-Aggression Theory. Retrieved from:

[21]. http://www.psychwiki.com/wiki/Frustration-Aggression Theory'Category.Concepts

[22]. Radu, M., (2001). The Futility for Root Causes of Terrorism. American Diplomacy, 27-5- 2001. Accessed From: http;//www.unc.edu/depts./diplomat/archives_roll/2002_07_09 on 28-2-2003

[23]. Shaw, J. S. (2012). Public Choice. The concise Encyclopaedia of economics. Retrieved From: http://www.ecolib.org/library.Enc/PublicChoice .html on July 20, 2012.

[24]. Tom, H., (2012). Povery and injustice drive Nigeria's sectarian violence. Retrieved from: http://www.reuters.com/news/world ; On December 9, 2012.

[25]. Tundun, A., July06, ( 2012). Boko Haram: The Beginning of Genocide. Tell Magazine

[26]. Wilke,E., (2012). The New Insecurity in a Globalized World. Retrieved From: http://sustainablesecurity.org/ On December 9, 2012. 